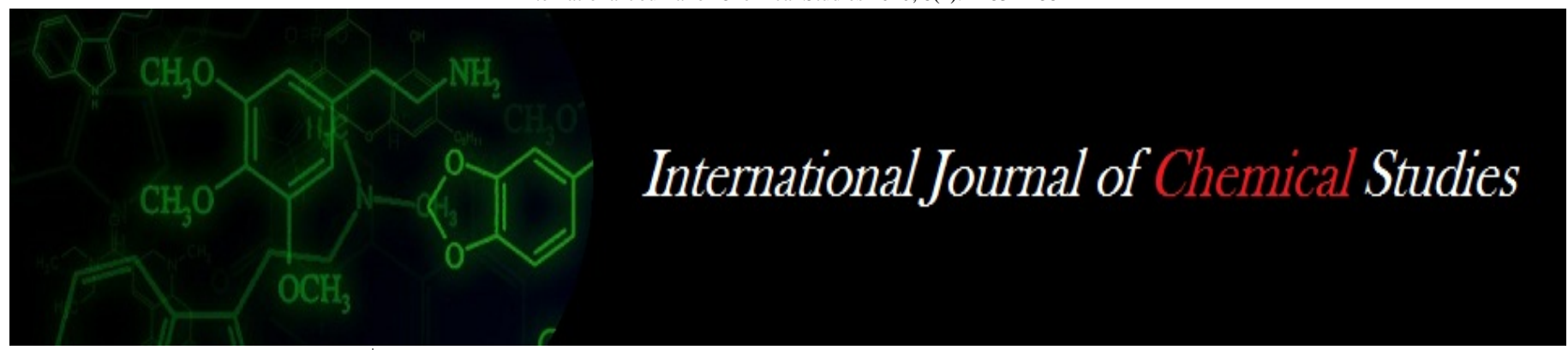

P-ISSN: 2349-8528

E-ISSN: 2321-4902

www.chemijournal.com

IJCS 2020; 8(4): 1283-1288

(C) 2020 IJCS

Received: 21-05-2020

Accepted: 23-06-2020

Prasanta Kumar Majhi

Department of Genetics and

Plant Breeding, College of

Agriculture, University of

Agricultural Sciences, Dharwad,

Karnataka, India

Suma C Mogali

AICRP on MULLARP, Main

Agricultural Research Station,

College of Agriculture,

University of Agricultural

Sciences, Dharwad, Karnataka,

India

\section{Abhisheka LS}

Department of Genetics and

Plant Breeding, College of

Agriculture, University of

Agricultural Sciences, Dharwad,

Karnataka, India
Corresponding Author:

Prasanta Kumar Majhi Department of Genetics and Plant Breeding, College of Agriculture, University of Agricultural Sciences, Dharwad, Karnataka, India

\section{Genetic Variability, Heritability, Genetic Advance and correlation studies for seed yield and yield components in early segregating lines $\left(F_{3}\right)$ of Greengram [Vigna radiata (L.) Wilczek]}

\author{
Prasanta Kumar Majhi, Suma C Mogali and Abhisheka LS
}

DOI: https://doi.org/10.22271/chemi.2020.v8.i4k.9779

\begin{abstract}
The present investigation was conducted with the $F_{3}$ breeding lines derived from three crosses viz., DGGV-7 $\times$ V-02-709, DGGV-7 $\times$ V-02-802, DGGV-2 $\times$ SML-1815 along with their parents used as checks. The progeny lines were evaluated for estimation of genotypic coefficient of variation (GCV), phenotypic coefficient of variation (PCV), heritability and genetic advance. The correlation study was undertaken among the ten selected quantitative characters. The analysis of variance showed, the progeny lines derived from the cross DGGV-7 $\times \mathrm{V}-02-709$, recoded very high significant variation for the characters like the number of branches per plant (2.988), pod length (2.363) and seed yield per plant (13.007g). The 100 seed weight (4.7g) was observed in the cross derivative of DGGV-2 $\times$ SML-1815 with high heritability 73.26 per cent and moderate genetic advance under mean (19.65). The breeding lines of DGGV-7 $\times$ V-02-709 have recorded mean seed yield $3.7 \mathrm{~g}$ with the range of 3.22 to $4.65 \mathrm{~g}$ and the PCV (17.35\%), GCV (14.23\%) was moderate with high heritability $(72.12 \%)$ coupled with moderate genetic advance over mean (17.45\%). There is a positive significant correlation was observed between plant height, number of clusters per plant, number of pods per plant, number of seeds per pod and seed yield per plant. Therefore, these characters should give higher priority at the time of selection for improvement of yield in greengram.
\end{abstract}

Keywords: PCV, GCV, heritability, genetic advance, correlation

\section{Introduction}

Greengram [Vigna radiata (L.) Wilczek] is a self-pollinated diploid $(2 n=2 x=2)$ crop with a genome size $579 \mathrm{Mb}$. This crop is a very nutritive pulse, rich in proteins and an ideal complement for the cereal-based balanced human diet. The nutritional composition in $100 \mathrm{~g}$ of mature grain contains protein $23.9 \mathrm{~g}$, fat $1.2 \mathrm{~g}$, carbohydrate $62.6 \mathrm{~g}$, dietary fiber $16.3 \mathrm{~g}$ and energy $347 \mathrm{kcal}$. This crop is considered as hardy pulse crop and grows well in a hot and dry climate and its cultivation improves soil fertility by adding about 30-40 kg N/ha after the harvest of the crop. Therefore, the succeeding crop (normally a cereal) requires about $25 \%$ less nitrogen application (Mbeyagala et al., 2017) ${ }^{[19]}$.

The highly self-pollinated nature of this crop reduces the natural variability which ultimately narrows down the effects of the selection process. But, the success of the selection programme in plant breeding depends on the magnitude of genetic variability in the population. Genetic variability and their quantification for qualitative and quantitative characters of economic importance are prerequisites for any crop improvement programme. Hence, the knowledge of variability, heritability and genetic advance become important for efficient breeding and it has great significance for the breeders in order to select the best genotypes for yield enhancement (Degafa et al., 2014) ${ }^{[7]}$.

The phenotypic variation observed in the field is the effect of both genetic and environmental variation. The presence of environmental variation makes the phenotypic variation less reliable and thus portioning of this into its components becomes a necessary step. Even the genotypic variation is deceiving when interaction effects are high, which is a non-heritable fraction. Thus, partitioning of phenotypic variation into heritable and non-heritable fractions is carried out. This is done with the help of certain genetic parameters such as Genotypic Coefficient of 
Variation (GCV), Phenotypic Coefficient of Variation (PCV), heritability and genetic advance. The knowledge of heritability coupled with genetic advance is useful in selecting the breeding programme and the correlation coefficient is important to understand the association between the yield and its contributing characters to find out guidelines for a better selection of quantitative traits (Johnson et al., 1955) ${ }^{[16]}$. By considering all these assessments, the present study was conducted to estimate genetic variability, heritability, genetic advance and correlation studies for seed yield and yield components in early segregating lines $\left(\mathrm{F}_{3}\right)$ of greengram.

\section{Materials and Methods}

The present investigation was carried out during Kharif-2017 at F-block, Experimental plot, AICRP on MULLaRP, Main Agricultural Research Station (MARS), College of Agriculture, University of Agricultural Sciences (UAS), Dharwad, Karnataka. The geographical position of the Farm is at $15^{\circ} 12^{\prime} \mathrm{N}$ latitude and $75^{\circ} 07^{\prime} \mathrm{E}$ longitudes with an altitude of $678 \mathrm{~m}$ above mean sea level. The materials used in the experiment were comprised of early segregating materials of three $\mathrm{F}_{3}$ generation crosses viz., DGGV-7 $\times$ V-02-709, DGGV-7 × V-02-802, DGGV-2 × SML-1815 along with their parents used as checks. The experiment was laid in an augmented design with spacing $10 \mathrm{~cm} \times 30 \mathrm{~cm}$ and each progeny and parental rows consist of more than 20 plants. All the recommended agronomical practices are followed to raise a good crop and better yield. The phenotypic observations recorded are days to 50 per cent flowering, plant height, number of branches per plant, number of clusters per plant, number of pods per cluster, number of pods per plant, pod length, number of seeds per pod, 100 seed weight and seed yield per plant. The data recorded on each of five randomly selected plants for different quantitative traits from each cross were averaged and statistical analysis was done using INDOSTAT version 8.1 and Microsoft Excel-2010.

The phenotypic and genotypic coefficients of variability (PCV and GCV) for all the characters were estimated using the formulae of Burton and De Vane (1953). The GCV and PCV values were categorized as low (0-10\%), moderate (10$20 \%$ ) and high (>20\%) as indicated by Shiva Subramanian and Menon (1973). Heritability (broad sense) was estimated for all the characters as the ratio of genotypic variance to the total variance as suggested by Lush (1949) and Hanson et al. (1956). According to Robinson et al. (1949), heritability estimates in cultivated plants can be placed in the categories; low (0-30\%), moderate (30-60\%) and high (> 60\%). Genetic advance for each character was estimated by using the formula of Johnson et al. (1955) ${ }^{[16]}$ and genetic advance as per cent of mean (GAM) was categorized according to him as low (0-10\%), moderate (10-20\%) and high (> 20\%).

\section{Results and Discussion \\ Analysis of variance and estimation of variability in $F_{3}$ generation}

The observations for the analysis of variance for the three breeding lines ( $\mathrm{F}_{3}$ generation) showed significant variation at 5 per cent and highly significant at 1 per cent level of probability. Most of the yields attributing characters for the breeding lines of greengram have shown significant variation. The progeny lines derived from the cross DGGV-7 $\times$ V-02709 , recoded very high significance for the characters like the number of branches per plant (2.988) pod length (2.363) and seed yield per plant (13.007g). The characters days to 50 per cent flowering and plant height (185.505) have shown significant variation at 5 per cent probability level. The check also have recoded for highly significant variation for most of the characters. Highly significant variation for the characters days to 50 per cent flowering, plant height, pod length, 100 seed weight, seed yield per plant was observed in the cross derivatives of DGGV-7 × V-02-802. Non-significant variation was observed for the characters number of branches per plant, number of pods per cluster. The progeny lines derived from DGGV-2 × SML-1815, shown highly significant variation for the characters days to 50 per cent flowering, plant height, number of pods per plant, 100 seed weight and seed yield per plant. But it was observed non-significant variation for the characters number of pods per cluster and number of seeds per pod (Table 1). Similar observations also recorded by Reddy et al. (2011) ${ }^{[27]}$, Prakash and Shekhawat (2012) ${ }^{[25]}$, Gadakh et al. (2013) ${ }^{[10]}$, Prasanna et al. (2013) ${ }^{[26]}$, Javed et al. (2014) ${ }^{[15]}$, Ahmad et al. (2015) ${ }^{[2]}$, Aparna et al. (2015) ${ }^{[4]}$, Das and Barua (2015) ${ }^{[6]}$, Muralidhara et al. (2015) ${ }^{[20]}$, Aalok et al. (2017) ${ }^{[1]}$ and Pavan et al. (2019) ${ }^{[23]}$.

\section{Estimates of PCV, GCV, heritability and genetic advance for yield components in the $F_{3}$ generation}

The genetic variability parameters such as mean, range, phenotypic coefficient of variation (PCV), genotypic coefficient of variation (GCV), heritability (broad sense) and genetic advance as per cent mean (GAM) for different characters are presented in Table 2.

Days to 50 per cent flowering: The days to 50 per cent flowering was observed early in the progeny lines derived from DGGV-7 $\times$ V-02-802 i.e. 40.42 days as compared to the other progeny lines. The phenotypic (2.36\%) and genotypic $(1.23 \%)$ coefficient of variation with low heritability (24.25\%) was observed these cross derivatives. The days to 50 per cent flowering of 41.32 days was recorded in the cross derivatives of DGGV-2 $\times$ SML-1815. The PCV and GCV was found to be 1.47 and 2.33 respectively. It also showed moderate heritability of 26.54 per cent which was highest among the three cross derivatives. All the three progeny lines showed early flowering as compared to the parents.

Plant height: High heritability (84.95\%) with high genetic advance under mean $(35.32 \%)$ was recorded for the progeny lines derived from the cross DGGV-7 $\times \mathrm{V}-02-709$ and the plant height ranged between 40.25 to $73.44 \mathrm{~cm}$. The phenotypic and genotypic coefficient of variation was observed in the cross derivatives of all the three crosses. The breeding lines derived from the cross DGGV-2 × SML-1815 showed PCV (33.54\%) and GCV (27.35\%) with high heritability of 83.24 per cent and high genetic advance over mean (24.6\%).

Number of branches per plant: Mean number of branches per plant was observed nearly equal in all cross derivatives of DGGV-7 × V-02-709 (4.68), DGGV-7 × V-02-802 (4.65) and DGGV-2 × SML-1815 (4.65). Heritability was higher in progeny lines derived from DGGV-7 $\times$ V-02-709 (85.67\%) with low genetic advance over mean. Higher PCV and GCV were recorded in the cross derivatives of DGGV-2 $\times$ SML1815 (26.55\% and $23.55 \%$ respectively).

Number of clusters per plant: The number of clusters per plant was observed in progeny lines of DGGV-2 $\times$ SML-1815 which was (8.23) with moderate PCV (19.62\%) and GCV (15.20\%), whereas the heritability and genetic advance under mean was recoded high for this cross. The range of number of clusters per plant was high (5.24 to 16.32) in the breeding 
lines of DGGV-7 $\times$ V-02-709 and the heritability was 42.54 per cent.

Number of pods per plant: The heritability of 80.25 and 76.45 per cent was observed for the progeny lines of DGGV-7 $\times \mathrm{V}-02-709$ and DGGV-7 $\times \mathrm{V}-02-802$ respectively. The genetic advance was recoded 65.45 per cent in the cross derivative of DGGV-7 $\times$ V-02-802 with phenotypic and genotypic coefficient of variation was 26.36 and 23.54 per cent. The cross derivative of DGGV-2 × SML-1815 have recoded mean number of pods per plant 16.54 and the PCV and GCV per cent was 56.23 and 38.94 per cent respectively.

Pod length: The mean pod length was observed $9.35 \mathrm{~cm}$ in the progeny lines of cross DGGV-2 $\times$ SML-1815 with range of 8.55 to $13.54 \mathrm{~cm}$ and the phenotypic and genotypic coefficient was recorded as moderate value 16.58 and 10.32 per cent respectively. The breeding lines derived from the cross DGGV-7 × V-02-709 recorded heritability of 57.65 per cent with low genetic advance over mean.

Number of seeds per pod: The Cross derivative of DGGV-7 $\times$ V-02-802 have recorded a higher mean number of seeds per pod (13.25) as compared to the other cross derivatives. Heritability of 62.55 per cent with moderate genetic advance over mean (19.55\%) was recorded for this cross. The progenies of DGGV-7 $\times \mathrm{V}-02-709$ recoded PCV (41.25\%) and GCV (37.10\%) with high heritability 64.78 per cent and moderate genetic advance over mean.
100 seed weight: The 100 seed weight $(4.7 \mathrm{~g})$ was observed in the cross derivative of DGGV-2 $\times$ SML-1815 with high heritability 73.26 per cent and moderate genetic advance under mean (19.65). The breeding lines of DGGV-7 $\times$ V-02709 have recorded mean seed yield $3.7 \mathrm{~g}$ with the range of 3.22 to $4.65 \mathrm{~g}$ and the PCV (17.35\%), GCV (14.23\%) was moderate with high heritability (72.12\%) coupled with moderate genetic advance over mean (17.45\%).

Heritability of a metric character is a parameter of particular significance to the breeder as it measures the degree of resemblance between the parents and the off-springs and its magnitude indicates the efficacy with which a genotype can be identified by its phenotypic expression, while genetic advance aids in exercising the necessary selection pressure. In the present investigation, it was observed the genotypic coefficient of variations and phenotypic coefficient of variations were close to each other and that most of the characters show high heritability coupled with high genetic advance. Hence, additive gene action plays a great role and environmental factors have a negligible effect on the traits. So selection is convenient to improve the traits for higher yield. These observations followed similar trends as observed earlier

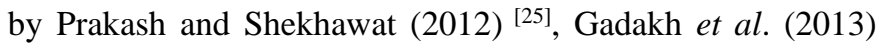
[10], Prasanna et al. (2013) ${ }^{[26]}$, Javed et al. (2014) ${ }^{[15]}$, Patel et al. (2014) ${ }^{[22]}$, Ahmad et al. (2015) ${ }^{[2]}$, Aparna et al. (2015) ${ }^{[4]}$, Das and Barua (2015) [6], Muralidhara et al. (2015) [20], Pinchhyo et al. (2016) ${ }^{[24]}$, Vir and Singh (2016) ${ }^{[31]}$, Parihar et al. (2018) ${ }^{[21]}$, Sandhya and Saravanan (2018) ${ }^{[29]}$; and Pavan et al. (2019) ${ }^{[23]}$.

Table 1: ANOVA for yield and component traits of greengram breeding lines in $F_{3}$ generation.

\begin{tabular}{|c|c|c|c|c|c|}
\hline \multirow{2}{*}{ Sl. No. } & \multirow{2}{*}{ Characters } & \multirow{2}{*}{ Crosses } & \multicolumn{3}{|c|}{ Mean Sum Squares (MSS) } \\
\hline & & & Checks & Progenies & Error \\
\hline \multirow{3}{*}{1} & \multirow{3}{*}{ Degree of freedom } & C1 & 3 & 19 & 12 \\
\hline & & $\mathrm{C} 2$ & 3 & 19 & 12 \\
\hline & & C3 & 3 & 19 & 12 \\
\hline \multirow{3}{*}{2} & \multirow{3}{*}{ Days to $50 \%$ flowering } & $\mathrm{C} 1$ & 2.654 & 0.389 & 0.268 \\
\hline & & $\mathrm{C} 2$ & 3.256 & 0.465 & 0.363 \\
\hline & & C3 & 2.915 & 0.397 & 0.401 \\
\hline \multirow{3}{*}{3} & \multirow{3}{*}{$\begin{array}{l}\text { Plant height } \\
\text { (cm) }\end{array}$} & C1 & $95.173^{*}$ & $105.758^{*}$ & 59.032 \\
\hline & & $\mathrm{C} 2$ & $84.173^{* *}$ & $102.758^{*}$ & 64.003 \\
\hline & & C3 & $98.913^{* *}$ & $109.628^{* *}$ & 64.122 \\
\hline \multirow{3}{*}{4} & \multirow{3}{*}{ Number of branches per plant } & C1 & $24.003^{* *}$ & 1.024 & 1.756 \\
\hline & & $\mathrm{C} 2$ & $35.643^{* *}$ & 1.059 & 1.948 \\
\hline & & $\mathrm{C} 3$ & $19.541^{* *}$ & 1.424 & 1.341 \\
\hline \multirow{3}{*}{5} & \multirow{3}{*}{ Number of clusters per plant } & C1 & $58.657^{* *}$ & 3.715 & 2.684 \\
\hline & & $\mathrm{C} 2$ & $54.057^{* *}$ & 3.514 & 2.541 \\
\hline & & C3 & $52.419^{* *}$ & 2.824 & 1.993 \\
\hline \multirow{3}{*}{6} & \multirow{3}{*}{ Number of pods per cluster } & $\mathrm{C} 1$ & 4.514 & 1.118 & 0.489 \\
\hline & & $\mathrm{C} 2$ & 4.268 & 1.040 & 0.682 \\
\hline & & C3 & 3.164 & 1.160 & 0.681 \\
\hline \multirow{3}{*}{7} & \multirow{3}{*}{ Number of pods per plant } & C1 & $17.912^{*}$ & 54.523 & 68.078 \\
\hline & & $\mathrm{C} 2$ & $156.912^{* *}$ & 54.321 & 74.007 \\
\hline & & C3 & $198.191^{* *}$ & 53.728 & 71.468 \\
\hline \multirow{3}{*}{8} & \multirow{3}{*}{ Pod length (cm) } & C1 & $15.630^{* *}$ & $1.328^{* *}$ & 0.365 \\
\hline & & $\mathrm{C} 2$ & $16.630^{* *}$ & $1.521^{* * *}$ & 0.268 \\
\hline & & C3 & $14.935^{* *}$ & $1.618^{*}$ & 0.363 \\
\hline \multirow{3}{*}{9} & \multirow{3}{*}{ Number of seeds per pod } & $\mathrm{C} 1$ & $16.508^{* *}$ & $3.056^{* *}$ & 1.004 \\
\hline & & $\mathrm{C} 2$ & $17.625^{* *}$ & $3.056^{* *}$ & 0.989 \\
\hline & & C3 & $15.924^{* *}$ & $2.626^{* *}$ & 1.126 \\
\hline \multirow{3}{*}{10} & \multirow{3}{*}{100 seeds weight (g) } & C1 & $4.165^{* *}$ & $31.423^{* *}$ & 0.189 \\
\hline & & $\mathrm{C} 2$ & $4.486^{* *}$ & $32.183^{* *}$ & 0.194 \\
\hline & & C3 & $3.461^{* *}$ & $31.284^{* *}$ & 0.193 \\
\hline \multirow{3}{*}{11} & \multirow{3}{*}{ Seed yield per plant (g) } & C1 & $49.628^{* *}$ & $9.053^{*}$ & 0.564 \\
\hline & & $\mathrm{C} 2$ & $54.025^{* *}$ & $9.524^{* *}$ & 0.589 \\
\hline & & C3 & $52.148^{* *}$ & $8.120^{* *}$ & 0.542 \\
\hline
\end{tabular}


Table 2: Estimate of variability (PCV and GCV), heritability and genetic advance for yield components in $\mathrm{F}_{3}$ generation of greengram breeding lines.

\begin{tabular}{|c|c|c|c|c|c|c|c|c|c|c|c|}
\hline \multirow{2}{*}{ Sl. No. } & \multirow{2}{*}{ Characters } & \multirow{2}{*}{ Crosses } & \multirow{2}{*}{ Parental mean } & \multirow{2}{*}{ Progeny mean } & \multicolumn{2}{|c|}{ Range } & \multirow{2}{*}{\begin{tabular}{|c|} 
PCV \\
$(\%)$
\end{tabular}} & \multirow{2}{*}{$\begin{array}{c}\text { GCV } \\
(\%)\end{array}$} & \multirow{2}{*}{\begin{tabular}{|l|}
$h^{2}$ bs \\
$(\%)$
\end{tabular}} & \multirow[t]{2}{*}{ GA } & \multirow{2}{*}{$\begin{array}{l}\text { GAM } \\
(\%)\end{array}$} \\
\hline & & & & & Maximum & Minimum & & & & & \\
\hline \multirow{3}{*}{1.} & \multirow{3}{*}{ Days to $50 \%$ flowering } & $\mathrm{C} 1$ & 42.35 & 40.52 & 38.53 & 41.37 & 2.36 & 1.23 & 22.33 & 0.65 & 1.62 \\
\hline & & $\mathrm{C} 2$ & 41.68 & 40.42 & 37.99 & 42.33 & 1.25 & 1.54 & 24.25 & 0.75 & 1.88 \\
\hline & & C3 & 41.26 & 41.32 & 35.46 & 43.11 & 1.47 & 2.33 & 26.54 & 0.78 & 1.89 \\
\hline \multirow{3}{*}{2.} & \multirow{3}{*}{$\begin{array}{l}\text { Plant height } \\
\text { (cm) }\end{array}$} & C1 & 51.26 & 49.66 & 40.25 & 73.44 & 25.45 & 21.54 & 84.95 & 17.53 & 35.32 \\
\hline & & $\mathrm{C} 2$ & 54.32 & 51.22 & 40.35 & 71.56 & 32.25 & 26.33 & 81.32 & 15.60 & 30.47 \\
\hline & & C3 & 58.70 & 54.28 & 44.56 & 70.55 & 33.54 & 27.35 & 83.24 & 13.33 & 24.56 \\
\hline \multirow{3}{*}{3.} & \multirow{3}{*}{ Number of branches per plant } & $\mathrm{C} 1$ & 5.83 & 5.52 & 4.23 & 6.54 & 23.56 & 20.02 & 85.23 & 0.38 & 7.02 \\
\hline & & $\mathrm{C} 2$ & 5.21 & 4.66 & 3.54 & 6.55 & 25.36 & 22.56 & 84.96 & 0.33 & 7.26 \\
\hline & & $\mathrm{C} 3$ & 4.96 & 4.65 & 3.21 & 6.88 & 26.55 & 23.25 & 74.56 & 0.32 & 6.98 \\
\hline \multirow{3}{*}{4.} & \multirow{3}{*}{ Number of clusters per plant } & C1 & 8.24 & 7.54 & 5.24 & 16.32 & 36.45 & 23.46 & 42.54 & 2.96 & 39.36 \\
\hline & & $\mathrm{C} 2$ & 7.96 & 7.66 & 4.95 & 14.12 & 32.25 & 22.31 & 55.36 & 3.49 & 45.63 \\
\hline & & C3 & 8.54 & 8.23 & 5.44 & 14.06 & 19.62 & 15.20 & 72.52 & 4.38 & 53.26 \\
\hline \multirow{3}{*}{5.} & \multirow{3}{*}{ Number of pods per clusters } & C1 & 7.98 & 7.54 & 5.24 & 16.32 & 36.45 & 23.46 & 70.25 & 4.18 & 55.46 \\
\hline & & $\mathrm{C} 2$ & 8.02 & 7.66 & 4.95 & 14.12 & 32.25 & 22.31 & 78.45 & 4.60 & 60.10 \\
\hline & & C3 & 5.62 & 4.23 & 3.21 & 5.32 & 23.44 & 20.39 & 88.52 & 2.85 & 67.58 \\
\hline \multirow{3}{*}{6.} & \multirow{3}{*}{ Number of pods per plant } & $\mathrm{C} 1$ & 15.68 & 15.45 & 11.05 & 28.65 & 26.36 & 23.54 & 80.65 & 10.11 & 65.45 \\
\hline & & $\mathrm{C} 2$ & 18.45 & 17.25 & 14.26 & 30.52 & 29.54 & 25.32 & 76.45 & 10.29 & 59.68 \\
\hline & & C3 & 18.62 & 16.54 & 9.85 & 30.22 & 56.23 & 38.94 & 39.45 & 4.93 & 29.85 \\
\hline \multirow{3}{*}{7.} & \multirow{3}{*}{$\begin{array}{l}\text { Pod length } \\
\text { (cm) }\end{array}$} & $\mathrm{C} 1$ & 8.74 & 8.45 & 7.42 & 10.32 & 13.25 & 9.32 & 57.65 & 0.70 & 8.32 \\
\hline & & $\mathrm{C} 2$ & 9.65 & 9.32 & 8.45 & 10.25 & 9.32 & 5.23 & 56.23 & 0.74 & 7.95 \\
\hline & & C3 & 9.86 & 9.35 & 8.55 & 13.54 & 16.58 & 10.32 & 43.15 & 0.56 & 6.06 \\
\hline \multirow{3}{*}{8.} & \multirow{3}{*}{ Number of seeds per pod } & $\mathrm{C} 1$ & 13.65 & 12.36 & 11.02 & 16.32 & 41.25 & 37.10 & 64.78 & 2.51 & 20.36 \\
\hline & & $\mathrm{C} 2$ & 13.98 & 13.25 & 12.03 & 16.24 & 40.25 & 35.84 & 62.55 & 2.59 & 19.55 \\
\hline & & C3 & 12.84 & 12.28 & 11.48 & 16.95 & 39.56 & 35.45 & 65.54 & 2.62 & 21.36 \\
\hline & & $\mathrm{C} 1$ & 4.10 & 3.7 & 3.22 & 4.65 & 17.35 & 14.23 & 72.12 & 0.64 & 17.45 \\
\hline 9. & 100 seed weight & $\mathrm{C} 2$ & 4.46 & 4.1 & 3.12 & 5.96 & 14.25 & 11.25 & 73.42 & 0.80 & 19.56 \\
\hline & & C3 & 5.24 & 4.7 & 3.05 & 5.69 & 14.32 & 12.34 & 73.26 & 0.92 & 19.65 \\
\hline & & $\mathrm{C} 1$ & 8.82 & 7.56 & 6.45 & 20.33 & 36.42 & 27.32 & 56.43 & 3.29 & 43.56 \\
\hline 10. & Seed yield per plant (g) & $\mathrm{C} 2$ & 9.20 & 8.55 & 6.99 & 18.42 & 36.44 & 25.99 & 48.32 & 3.35 & 39.25 \\
\hline & & C3 & 10.40 & 9.86 & 7.54 & 17.22 & 22.54 & 19.65 & 67.45 & 5.04 & 51.12 \\
\hline
\end{tabular}

Where, PCV- Phenotypic coefficient of variation, GCV- Genotypic coefficient of variation, $\mathrm{h}^{2}(\mathrm{bs})$ - Broad sense heritability, GA- Genetic advance, GAM- Genetic advance as per cent mean, C1- DGGV-7 × V-02-709, C2- DGGV-7 × V-02-802, C3- DGGV-2 × SML-1815

\section{Correlation studies among different yield attributing traits in the $F_{3}$ generation}

The concept of correlation was initially proposed by Galton (1889) ${ }^{[11]}$. Further, it was detailed by Fisher (1918) ${ }^{[9]}$ and Wright (1921) ${ }^{\text {[32] }}$. Correlation coefficient analysis is a handy technique, which elaborates the degree and extent of the relationship among important plant characters and it provides basic criteria for selection based on yield and its components in the field experiments. Information regarding inheritance of grain yield and its closely related components is essential to efficiently exploit the available genetic diversity in green gram for seed yield (Khattak et al., 2001) ${ }^{[17]}$. The genetic architecture of seed yield per plant in green gram is formulated by the complex interaction of yield attributes. Therefore, understanding these interrelationships is necessary before planning any selection strategy. The significant and non-significant correlations between the yield attributing traits are represented in Table 3.

The progeny lines obtained from DGGV-7 $\times$ V-02-709 showed highly significant correlation od plant height with the characters like number of clusters per plant (0.425), number of pods per plant (0.359), pod length (0.352), number of seeds per pod (0.429) and seed yield per plant (0.542) with plant height. A highly significant correlation was recorded between the number of branches per plant with the number of clusters per plant (0.522) and the number of pods per plant (0.523) in the breeding lines derived from the crosses DGGV-7 $\times \mathrm{V}-02-$ 709. The progenies of DGGV-7 $\times$ V-02-802 has shown highly significant correlation between number of branches with number of clusters per plant (0.635), number of pods per plant (0.325), pod length (0.478) and seeds per pod (0.502), but it significant relation was recorded for seed yield per plant (0.458). High significant relation for the number of branches per plant (0.566), pod length (0.476) and seeds per pod (0.485), whereas significant relation observed for seed yield per plant (0.346) for the cross derivatives of DGGV-2 $\times$ SML-1815.

The number of clusters per plant was recorded high a significant relation with the number of pods per plant (0.557) and seed yield per plant (0.988) for the cross derivatives of DGGV-7 × V-02-709. A highly significant correlation was also recorded in the breeding lines of DGGV-7 $\times$ V-02-802 (0.623) and DGGV-2 $\times$ SML-1815 (0.744) for the characters among the number of clusters per plant and number of pods per plant. The number of pods per plant was highly significant with seed yield per plant in the progeny lines of DGGV-7 $\times$ V-02-709 (0.744) and the lines from DGGV-7 $\times$ V-02-802, DGGV-2 $\times$ SML-1815 also shown high significant relation with 0.9 .1 and 0.854 respectively. There is a positive significant correlation was observed between plant height, number of clusters per plant, number of pods per plant, number of seeds per pod and seed yield per plant. So it confirms that these inter-related characters are easy to improve for higher yield through careful selection. These results are an agreement with the findings of Hemavathy et al. (2015) ${ }^{[14]}$; Anand et al. (2016) ${ }^{[3]}$, Pinchhyo et al. (2016) ${ }^{[24]}$, Dhoot et al. (2017) ${ }^{[8]}$, Parihar et al. (2018) ${ }^{[21]}$, Sandhya et al. $(2018)^{[29]}$. 
Table 3: Phenotypic correlation study for yield and component traits in breeding lines of greengram ( $\mathrm{F}_{3}$ generation).

\begin{tabular}{|c|c|c|c|c|c|c|c|c|c|c|}
\hline \multicolumn{2}{|c|}{ Yield attributing traits } & \multirow{2}{*}{\begin{tabular}{|c|}
$\begin{array}{c}\text { Days to 50 \% } \\
\text { flowering }\end{array}$ \\
1 \\
\end{tabular}} & \multirow{2}{*}{\begin{tabular}{|c|}
$\begin{array}{c}\text { Plant } \\
\text { height }\end{array}$ \\
0.068 \\
$-0.750^{* *}$ \\
0.075 \\
\end{tabular}} & \multirow{2}{*}{$\begin{array}{c}\begin{array}{c}\text { Number of } \\
\text { branches per plant }\end{array} \\
0.144 \\
0.023 \\
0.043 \\
\end{array}$} & \multirow{2}{*}{\begin{tabular}{|c|}
$\begin{array}{c}\text { Number of } \\
\text { clusters per plant }\end{array}$ \\
0.165 \\
-0.074 \\
$0.285^{*}$ \\
\end{tabular}} & \multirow{2}{*}{\begin{tabular}{|c|c|}
$\begin{array}{c}\text { Number of } \\
\text { pods per plant }\end{array}$ \\
$0.212^{*}$ \\
$-0.235^{*}$ \\
$0.232^{*}$ \\
\end{tabular}} & \multirow{2}{*}{\begin{tabular}{|c}
$\begin{array}{c}\text { Pod } \\
\text { t length }\end{array}$ \\
0.042 \\
-0.019 \\
0.065 \\
\end{tabular}} & \multirow{2}{*}{\begin{tabular}{|c|}
$\begin{array}{c}\text { Seeds } \\
\text { per pod }\end{array}$ \\
0.098 \\
-0.203 \\
0.125 \\
\end{tabular}} & \multirow{2}{*}{\begin{tabular}{|c|}
$\begin{array}{c}\text { 100 seed } \\
\text { weight }\end{array}$ \\
-0.156 \\
0.011 \\
0.230 \\
\end{tabular}} & \multirow{2}{*}{\begin{tabular}{|c|}
$\begin{array}{c}\text { Seed yield } \\
\text { per plant }\end{array}$ \\
0.174 \\
$-0.398^{*}$ \\
0.126 \\
\end{tabular}} \\
\hline $\begin{array}{l}\text { Days to } 50 \text { per } \\
\text { cent flowering }\end{array}$ & \begin{tabular}{|l|} 
C1 \\
C2 \\
C3
\end{tabular} & & & & & & & & & \\
\hline Plant height & \begin{tabular}{l|}
$\mathrm{C} 1$ \\
$\mathrm{C} 2$ \\
$\mathrm{C} 3$ \\
\end{tabular} & & 1 & $\begin{array}{c}0.234 \\
-0.056 \\
0.346\end{array}$ & $\begin{array}{c}0.425^{* *} \\
0.321 \\
0.422\end{array}$ & $\begin{array}{c}0.359^{* *} \\
0.623^{* *} \\
0.425\end{array}$ & $\begin{array}{l}0.352^{* *} \\
-0.033 \\
0.443^{*+}\end{array}$ & $\begin{array}{c}0.429^{* *} \\
0.213 \\
0.556^{* *}\end{array}$ & $\begin{array}{c}-0.164 \\
-0.122 \\
0.025\end{array}$ & $\begin{array}{c}0.542^{* *} \\
0.435^{* *} \\
0.462\end{array}$ \\
\hline $\begin{array}{c}\text { Number of } \\
\text { branches per plant }\end{array}$ & \begin{tabular}{l|} 
C1 \\
C2 \\
C3 \\
\end{tabular} & & & 1 & $\begin{array}{l}0.522^{* *} \\
0.635^{* *} \\
0.566^{* *}\end{array}$ & $\begin{array}{l}0.523^{* *} \\
0.325^{* *} \\
0.456^{* *}\end{array}$ & $\begin{array}{l}0.063 \\
0.478^{* *} \\
0.476^{* *}\end{array}$ & $\begin{array}{c}0.125 \\
0.502^{* *} \\
0.485^{* *} \\
\end{array}$ & $\begin{array}{c}0.233^{*} \\
0.018 \\
0.321^{*}\end{array}$ & $\begin{array}{l}0.512^{* *} \\
0.458^{*} \\
0.346^{*}\end{array}$ \\
\hline $\begin{array}{c}\text { Number of clusters } \\
\text { per plant }\end{array}$ & $\begin{array}{l}\text { C1 } \\
\text { C2 } \\
\text { C3 }\end{array}$ & & & & 1 & $\begin{array}{l}0.557^{* *} \\
0.623^{* *} \\
0.744^{* *}\end{array}$ & $\begin{array}{c}0.268^{*} \\
0.395 \\
* * \\
0.243 \\
\end{array}$ & \begin{tabular}{|c|}
$0.402^{* *}$ \\
0.289 \\
0.166
\end{tabular} & $\begin{array}{c}0.074 \\
-0.042 \\
0.045\end{array}$ & $\begin{array}{l}0.988^{* *} \\
0.860^{* *} \\
0.845^{* *}\end{array}$ \\
\hline $\begin{array}{l}\text { Number of pods } \\
\text { per plant }\end{array}$ & \begin{tabular}{|l|} 
C1 \\
C2 \\
C3
\end{tabular} & & & & & 1 & $\begin{array}{l}0.128 \\
0.202 \\
0.132\end{array}$ & $\begin{array}{l}0.221^{*} \\
0.232 \\
0.234\end{array}$ & $\begin{array}{c}0.065 \\
-0.245 \\
0.045\end{array}$ & $\begin{array}{l}0.744^{* *} \\
0.901^{* *} \\
0.854^{* *}\end{array}$ \\
\hline Pod length & \begin{tabular}{l|}
$\mathrm{C} 1$ \\
$\mathrm{C} 2$ \\
$\mathrm{C} 3$ \\
\end{tabular} & & & & & & 1 & $\begin{array}{l}0.612^{* *} \\
0.685^{* *} \\
0.588^{* *} \\
\end{array}$ & \begin{tabular}{|c}
$-0.315^{* *}$ \\
-0.062 \\
0.042 \\
\end{tabular} & $\begin{array}{c}0.257^{*} \\
0.231 \\
0.036 \\
\end{array}$ \\
\hline Seeds per pod & \begin{tabular}{|l|} 
C1 \\
C2 \\
C3 \\
\end{tabular} & & & & & & & 1 & $\begin{array}{l}-0.133 \\
-0.185\end{array}$ & $\begin{array}{c}0.468^{* *} \\
0.128 \\
0.456\end{array}$ \\
\hline 100 seed weight & \begin{tabular}{|l|} 
C1 \\
C2 \\
\end{tabular} & & & & & & & & 1 & $\begin{array}{c}0.089 \\
-0.195 \\
0.201 \\
\end{array}$ \\
\hline
\end{tabular}

*and $^{* *}$ - Significant at $5 \%$ and $1 \%$ probability level respectively. Where, C1- DGGV-7 $\times$ V-02-709, C2- DGGV-7 × V-02-802, C3- DGGV-2 $\times$ SML-1815

\section{Conclusion}

As such, before launching any breeding programme, a thorough knowledge of the nature and magnitude of genetic variability and extent of association between yield and other attributing traits is very essential. Because seed yield is a complex character and depends on the number of component characters, which are quantitatively inherited. High magnitude of phenotypic and genotypic coefficient of variation was observed for the characters plant height, number of branches per plant, number of clusters per plant and number of seeds per pod in the advance breeding lines derived from the crosses viz; DGGV-7 × V-02-709, DGGV-7 × V-02-802 and DGGV$2 \times \mathrm{SML}-1815$ in $\mathrm{F}_{3}$ generation. Moderate to high heritability was observed for most of the yield attributing characters in the advance segregating populations coupled with moderate to high genetic advance over mean. High values of these parameters indicate wider variability and vice versa. In the same context, narrow differences between the phenotypic coefficient of variation (PCV) and genotypic coefficient of variation (GCV) implies the lesser influence of environment on these traits. The environment has a profound influence on the economically important characters, which are quantitatively inherited. Therefore, it is difficult to decide upon whether the observed variability is heritable or due to environment. Therefore, it is necessary to partition the same into its heritable and non-heritable components with suitable parameters like genetic coefficient, heritability estimates and genetic advance. Understanding the relationship between these characters helps in improving the desired character through direct and indirect improvement in many other characters. The correlation study examines the possibility of improving yield through the indirect selection of yield attributes. The correlation coefficient between yield and its attributing traits were worked out in order to determine the extent of association with each component traits. A high correlation was recorded between the number of branches per plant with number of clusters per plant, number of pods per plant and seed yield per plant in all the three segregating populations. The progeny lines derived from DGGV-7 $\times \mathrm{V}$ 02-709 showed higher heritability, more PCV and GCV for most of the characters, as compared to the other two cross derivatives; it needs special attention at the time of selection. Hence, the characters of higher heritability coupled with high and high significant correlation among the traits should give prior importance at the time of selection for yield improvement in green gram.

\section{References}

1. Aalok S, Vinita R, Vadodariya GD, Modha KG, Patel RK. Genetic variability, heritability and genetic advance in $\mathrm{F}_{3}$ progenies of mungbean [Vigna radiata (L.) Wilczek]. International Journal of Current Microbiology and Applied Sciences. 2017; 6(12):3086-3094.

2. Ahmad HB, Rauf F, Hussain I, Rafiq CM, Rehman A, Aulakh AM. Genetic variability, association and path analysis in mung bean [Vigna radiata (L.) Wilczek]. International Journal of Agronomy and Agricultural Research. 2015; 6(6):75-81.

3. Anand G, Anandhi K, Paulpandi VK. Genetic variability, correlation and path analysis for yield and yield components in $\mathrm{F}_{6}$ families of Greengram [Vigna radiata (L.) Wilczek] under rainfed condition. Electronic Journal of Plant Breeding. 2016; 7(1):434-437.

4. Aparna R, Singh SK, Vinay S, Rakesh P. Genetic variability, heritability, genetic advance and path analysis in mungbean [Vigna radiata (L.) Wilczek]. Legume Research. 2015; 38(2): 157-163.

5. Burton GW, De Vane EM. Estimating heritability in tall fescue (Festuca arundinaceae) from replicated clonal material. Agronomy Journal. 1953; 51(5):515-518.

6. Das RT, Barua PK. Association studies for yield and its components in green gram. International Journal of 
Agriculture, Environment and Biotechnology. 2015; 8(3):561-565.

7. Degefa I, Petros Y, Andargie M. Genetic variability, heritability and genetic advance in mungbean [Vigna radiata (L.) Wilczek] accessions. Plant Science Today. 2014; 1(2): 94-98.

8. Dhoot Rupal KG, Modha DK, Dhoot M. Correlations and Path Analysis Studies on yield and its components in mungbean [Vigna radiata (L.) Wilczek] International Journal of Current Microbiology and Applied Sciences. 2017; 6(5):370-378.

9. Fisher RA. The correlation between relatives on the supposition of Mendelian inheritance. Trans. Rev. Soc. Edinburgh. 1918; 52(7):399-433.

10. Gadakh SS, Dethe AM, Kathale MN. Genetic variability, correlations and path analysis studies on yield and its components in mungbean [Vigna radiata (L.) Wilczek]. Bioinfolet. 2013; 10(2A):441-447.

11. Galton F. Natural Inheritance, McMillan and Co., London (UK), 1889, 74-75.

12. Gowda CLL, Sunil KC, Gaur PM, Kumar CVS, Arvind KJ. Pulses Research and Development Strategies for India. IIPR, Pulses Handbook, 2015, 17-27.

13. Hanson GH, Robinson HF, Comstock RE. Biometrical studies of yeld in segregating populations of Koren Lependeza. Agronomy Journal. 1956; 48(1):267-282.

14. Hemavathy AT, Shunmugavalli N and Anand G. Genetic variability, correlation and path coefficient studies on yield and its components in mungbean [Vigna radiata (L.) Wilczek]. Legume Research. 2015; 38(4):442-446.

15. Javed I, Ahmad HM, Ahsan M, Ali Q, Ghani MU, Iqbal MS. Induced genetic variability by gamma radiation and traits association study in mungbean [Vigna radiata (L.) Wilczek]. Life Science Journal. 2014; 11(8):530-539.

16. Johnson HW, Robinson HI and Comstock RE. Estimation of genetic and environmental variability in soybean. Agronomy Journal. 1955; 47(3):314-318.

17. Khattak GSS, Haq MA, Ashraf M, Srinivas $P$. Combining ability in mungbean [Vigna radiata (L.) Wilczek]. Agronomic traits. Korean Journal Crop Science. 2001; 46:420-423.

18. Lush JL. Heritability of quantitative characters in farm animals. Proc. 85 ${ }^{\text {th }}$ Cong. Genetics, 1949, 356-375.

19. Mbeyagala KE, Amayo R, Obuo JP, Abhay KP, Abdul RW. A manual for mungbean production in Uganda. National Agricultural Research Organization (NARO), 2017, 32.

20. Muralidhara YS, Lokesh Kumar BM, Uday G, Shanthala J. Studies on genetic variability, correlation and path analysis of seed yield and related traits in green gram [Vigna radiata L. Wilczek]. International Journal of Agricultural Science and Research. 2015; 5(3):125-132.

21. Parihar RA, Agrawal P, Sharma DJ, Minz MG. Character association and path analysis studies on seed yield and its yield attributing traits in mungbean [Vigna radiata (L.) Wilczek]. Journal of Pharmacognosy and Phytochemistry. 2018; 7(1):2148-2150.

22. Patel SR, Patel KK, Parmar HK. Genetic variability, correlation and path analysis for seed yield and its components in green gram [Vigna radiate (L.) Wilczek]. The Bioscan. 2014; 9(4):1847-1852.

23. Pavan K, Reddy P, Mehta, CM. Estimation of variability through genetic parameters and identification of superior pure lines for yield attributing traits in green gram [Vigna radiata (L.) Journal of Pharmacognosy and Phytochemistry. 2019; 3:55-61.

24. Pinchhyo B, Lal GM, Neha T. Studies on genetic variability, correlation and path analysis in greengram [Vigna radiata (L.) Wilczek] germplasm. International Journal of Agriculture Sciences. 2016; 8(51):2267-2272.

25. Prakash V, Shekhawat US. Analysis of genetic diversity in newly developed genotypes of mungbean [Vigna radiata (L.) Wilczek]. Journal of Progressive Agriculture. 2012; 3(2):47-50.

26. Prasanna BL, Rao PJM, Murthy KGK, Prakash KK. Genetic variability, correlation and path coefficient analysis in mungbean. Environment and Ecology. 2013; 31(4):1782-1788.

27. Reddy DKR, Venkateswarlu O, Obaiah MC, Siva Jyothi GL. Studies on genetic variability, character association and path coefficient analysis in greengram [Vigna radiata (L.) Wilczek]. Legume Research. 2011; 34(3):202-206.

28. Robinson HF, Comstock RE and Harvey PH. Estimation of heritability and degree of dominance in corn. Agronomy Journal. 1949; 41(3):353-359.

29. Sandhiya V, Saravanan S. Genetic variability and correlation studies in greengram [Vigna radiata (L.) Wilczek]. Electronic Journal of Plant Breeding. 2018; 9(3):1094-1099.

30. Sivasubramanian S, Menon M. Heterosis and inbreeding depression in rice. Madras Agriculture Journal. 1973; 60(5):1339.

31. Vir O, Singh AK. Analysis of morphological characters interrelationships in the germplasm of mungbean [Vigna radiata (L.) Wilczek] in the hot arid climate. Legume Research. 2016; 39(1):14-19.

32. Wright S. Correlation, causation and Wright's theory of Path-Coefficients. Journal of Agricultural Research. 1921; 20:557-585. 